\title{
小型船舶および動摇装置による動摇に対する 生体の立位姿勢動摇と運動負荷
}

\section{坂牧 孝規 ${ }^{1} \cdot$ 土井根 礼音 $^{2} \cdot$ 瀬田 $\quad$ 広明 ${ }^{3} \cdot$ 小川 伸夫 $^{4}$ \\ Exercise Load and Physical Motion on Standing Posture in a Small Marine Craft and Motion System}

\section{Takanori SAKAMAKI, Renon DOINE, Hiroaki SETA and Nobuo OGAWA}

\begin{abstract}
The purpose of this study was to develop method of evaluating a motion system using motion on standing posture and exercise load. In this paper, we report participants' motion on standing posture, participants' exercise load during standing on the motion system and compared with those on a marine craft.

The measurement system consisted of three orientation sensors and a calorimeter. Orientation sensors capable of measuring linear and angular accelerations were placed on the head and waist of each participant, and on the floor of a small marine craft. Energy expenditure was measured using the calorimeter. In the small marine craft, participants were either sitting or standing. In the laboratory, participants were sitting, or standing on the motion system. Motion on standing posture was analyzed by calculating the root mean square (RMS). Exercise load was calculated by dividing the mean energy expenditure in each condition by that in the sitting condition.

Passengers' motion on standing posture on the craft was mainly rotational motion. The exercise load during performing motion system was similar to that during standing on the craft. We thus suggested that motion on standing posture and exercise load are proved effective in evaluating a motion system.

Keywords : human engineering, motion on standing posture, exercise load, small marine craft, motion system キーワード : 労働・人閒工学、立位姿勢動摇、運動負荷、小型船舶、動摇装置

\section{1. はじめに}

船舶に乗船すると、ほとんどの人たちは疲労を感 じ、船舶が小さくなるほどその傾向は強い。しかし、 船舶乗船時の疲労の原因の特定や、その定量化に関 する研究はほとんど行われていない。

船舶事故の原因の $90 \%$ は人的要因によるものと されている(1)。疲労は、ヒューマンエラー（見張り 不十分）の原因の 1 つとして考えられており ${ }^{(2)}$ 、船 舶職員の疲労の適切な対応策が求められている。

これまでに、筆者らは、小型船舶の動摇に対する 乗船者の立位姿勢動摇を計測するとともに、立位姿 勢動摇によって生じる生体の運動負荷を算出するこ とで、船舶動摇が乗船者に与える生理的影響を解析 してきた ${ }^{(3)}$ (4)。一方、小型船舶で同一の動摇を再現 することは困難であり、生体の状態も個体差や時系 列変化が生じる。このため、船舶動摇と同等な動摇 を再現することが可能な研究環境の構築が必要とな る。

1 正会員 鳥羽商船高等専門学校（†517-8501 三重県鳥羽市池上町 1 番 1 号) takanori@sakamaki-lab.jp

2 正会員 東京電機大学 （广120-8551 東京都足立区千住旭町 5 番）

3 正会員 鳥羽商船高等専門学校 （†517-8501 三重県鳥羽市池上町 1 番 1 号）

4 非会員 鳥羽商船高等専門学校（广517-8501 三重県鳥羽市池上町 1 番 1 号）
\end{abstract}


本研究は、船舶動摇に対する乗船者の疲労などの 研究環境を構築するための基礎研究として、生体の 立位姿勢動摇と運動負荷を指標とした動摇装置の評 価手法の構築を目的とする。一般に、並進運動とし て前後摇れ（Surge）、左右摇れ (Sway)、上下摇れ (Heave)、回転運動として横摇れ（Ro11）、縦摇れ (Pitch)、船首摇れ（Yaw）の動摇を再現する動摇装 置は高価である。このため、本研究は、上下摇れ (Heave)、横摇れ (Roll)、縦摇れ (Pitch) の動摇 を再現する簡易型動摇装置を用いた研究環境の構築 の可能性について検討を行ったので報告する。

\section{2. 方法}

\section{1 計測システム}

船舶または簡易型動摇装置の床の動摇に対する 生体の立位姿勢動摇の計測は、船舶または簡易型動 摇装置の床、乗船者の腰部、頭部に設置した 3 台の 3 軸方位角センサを用いて、各部位の加速度 ・角加 速度を計測することにより行った。加速度 - 角加速 度の計測インターバルは、 $0.01 \mathrm{~s}$ とした。

立位姿勢動摇によって生じる生体のエネルギー 消費量を、呼気量と $0_{2}$ 濃度の計測により算出するエ ネルギー代謝計 ${ }^{(5)}$ を用いて計測した。エネルギー消 費量の計測インターバルは、10s とした。

\section{2 評価指標}

\section{2.1 立位姿勢動摇}

船舶の床、生体の腰部、頭部に設置した 3 軸方位 角センサは、各々独立した座標系をもち、その傾き に応じた重力加速度の影響を受ける。本研究では、 船体近傍の地球表面の接平面に、船舶の前方を $\mathrm{x}$ 軸 のプラス方向、船舶の右側を $\mathrm{y}$ 軸のプラス方向、地 球の中心に向かう軸を $\mathrm{z}$ 軸のプラス方向とし、 $\mathrm{x}-\mathrm{y}$ 平面を水平面とした固定座標系を定義し、各 3 軸方 位角センサの加速度、角速度を固定座標系に変換し 解析を行った ${ }^{(6)}$ 。

並進運動は、前後摇れ (Surge)、左右摇れ (Sway)、 上下摇れ（Heave）とした。回転運動は、座標変換を 適用した角速度を微分した角加速度を算出し横摇れ

(Ro11)、縦摇れ (Pitch)、船首摇れ (Yaw) とした。 なお、上下摇れに含まれる重力加速度は、 9. $80665 \mathrm{~m} / \mathrm{s}^{2}$ を減じることで除去した。

動摇の大きさは、船舶の床、生体の腰部、頭部の 加速度・角加速度の実効值 (Root Mean Square : RMS) として算出した。実効値とは、時系列波形がもつ任
意の時間内における平均的な強さを意味する。実効 值は式(1)により定義される ${ }^{(7)}$ 。式中の fi は加速度 または角加速度であり、N はデータ数である。本研 究では、生体の立位姿勢動摇を抽出するために、カ ットオフ周波数 $15 \mathrm{~Hz}$ のローパスフィルタを加速度、 角加速度データに適用した。

$$
R M S\left(f_{i}\right)=\sqrt{\frac{1}{N} \sum_{i=0}^{N-1}\left(f_{i}\right)^{2}}
$$

\subsection{2 運動負荷}

運動に要するエネルギー量や運動の強さを表す 指標として、METS (Metabolic Equivalent)が定義さ れている。これは、運動時のエネルギー代謝量を安 静時のエネルギー代謝量で除した值であり、運動に よる全代謝量が安静時の何倍であるかを示す ${ }^{(8)}$ 。

本研究では、運動負荷を、METS を参考に、気温等 の環境要因による誤差を少なくするために、立位姿 勢時のエネルギー消費量を、安静時のエネルギー消 費量を除した值と定義した（式(2)）(4)。なお、安静 時のエネルギー消費量は、座位姿勢時のエネルギー 消費量とし、エネルギー消費量は 10 分間 (60データ) の平均值とした。

運動負荷 $=\frac{\text { 立位姿勢時のエネルギー消費量 }}{\text { 安静時のエネルギー消費量 }}$

\section{3 実験概要}

実験は、鳥羽商船高等専門学校生命倫理委員会規 則に則り実施された。被験者には実験開始前に実験 内容の説明を行い、実験への参加について同意を得 た。

\section{3.1 小型船舶を用いた実験}

小型船舶を用いた実験は、図 1 に示寸鳥羽商船高 等専門学校が所有する実習船「あさま」(半滑走型、 総トン数 $14 \mathrm{t}$ 、定員 23 名）の船舶内で実施した。小 型船舶内の実験風景を図 2 に示す。小型船舶の速度 は可能な限り一定（16.0〜19.9 knot）とし、急な変 針は行わないようにした。なお、実験は複数日実施 し、その際の気象海象は風速が $1.9 \sim 4.2 \mathrm{~m} / \mathrm{s}$, 波高 は全日とも $0.30 \mathrm{~m}$ 以下であった。視覚情報を排除す るために、被験者の立位姿勢動摇は、船舶動摇の予 
測を可能とする船外の風景が見えない場所で計測し た。被験者には、(1)座位 $15 \mathrm{~min}$ 、立位 $15 \mathrm{~min}$ 、座位 $15 \mathrm{~min}$ 、立位 $15 \mathrm{~min}$ 、座位 $15 \mathrm{~min}$ 、または(2)座位 $25 \mathrm{~min}$ 、 立位 $25 \mathrm{~min}$ 、座位 $15 \mathrm{~min}$ の姿勢をとり、開眼状態で、 船首方向である船内の壁を正面とするように指示し た。座位姿勢の際は、被験者を船舶内に固定された クッション性のある椅子に座らせた。

\subsection{2 動摇装置を用いた実験}

簡易型動摇装置の動摇面を図 3 に示す。これは、 並進運動の上下摇れ (Heave)、回転運動の横摇れ

(Rol1)、縦摇れ (Pitch) の動きを、一辺 $1.0 \mathrm{~m} の$ 正三角形の板に発生させる。動摇は、板の各頂点が 台車の上に垂直に立てられたボールねじに接続され、 AC サーボモータを用いて、ボールねじの回転を制御 することで調整される。

動摇装置によって発生させる動摇は、板の中心点 に於いて、表 1 に示す基本摇れに、加算摇れ $1 \sim 5$ を加えた波形を発生させた。基本摇れおよび加算摇

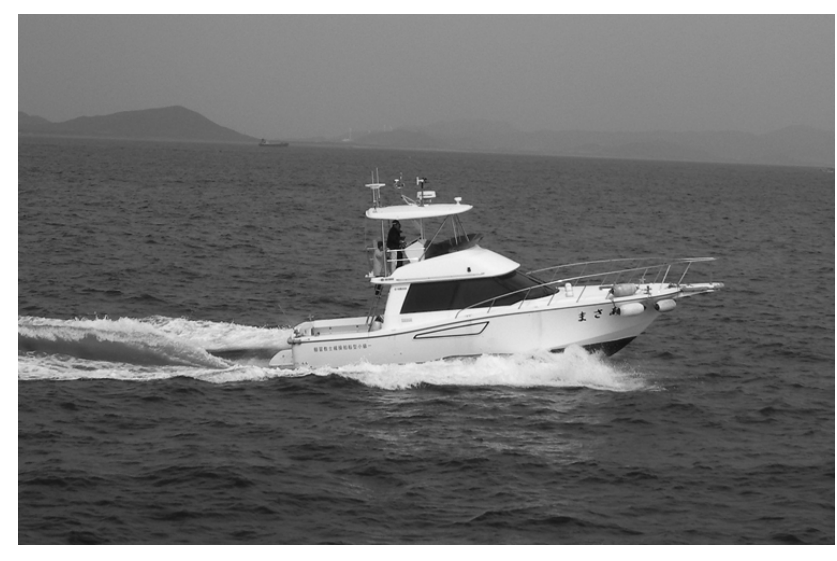

図 1 実習船「あさま」

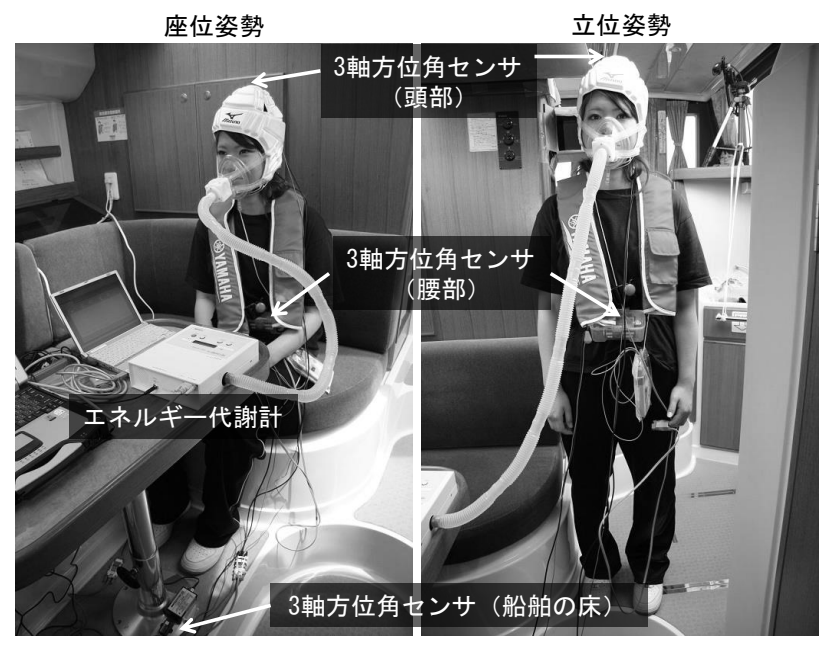

図 2 小型船舶を用いた実験風景
れの波形は、 $\sin$ 波（正弦波）とした。これは、前 述の小型船舶を用いた実験で計測した船舶の床の動 摇について、周波数解析を行い、周波数成分として 含まれる摇れを組み合わせたものである。

動摇装置を用いた実験風景を図 4 に示す。これは、 図 3 で示した簡易型動摇装置の動摇面上で、被験者 が立っている状態を示している。被験者には、椅子 で座位 $15 \mathrm{~min}$ 、動摇装置上で立位 $15 \mathrm{~min}$ の姿勢をと り、開眼状態で正面を見るように指示した。

表 1 動摇装置で発生させた動摇

\begin{tabular}{|c|c:c:c|}
\hline & 上下摇れ(Heave) & 横摇れ(Roll) & 縦摇れ(Pitch) \\
\hline 基本摇れ & $\pm 0.06 \mathrm{~m}, 0.80 \mathrm{~Hz}$ & $\pm 0.58^{\circ}, 0.20 \mathrm{~Hz}$ & $\pm 1.73^{\circ}, 0.50 \mathrm{~Hz}$ \\
\hline 加算摇れ 1 & - & - & $\pm 1.27^{\circ}, 0.04 \mathrm{~Hz}$ \\
\hline 加算摇れ2 & $\pm 0.03 \mathrm{~m}, 0.04 \mathrm{~Hz}$ & $\pm 3.42^{\circ}, 0.04 \mathrm{~Hz}$ & $\pm 1.27^{\circ}, 0.04 \mathrm{~Hz}$ \\
\hline 加算摇れ3 & $\pm 0.03 \mathrm{~m}, 0.04 \mathrm{~Hz}$ & $\pm 8.42^{\circ}, 0.04 \mathrm{~Hz}$ & $\pm 1.27^{\circ}, 0.04 \mathrm{~Hz}$ \\
\hdashline 加算摇れ4 & $\pm 0.03 \mathrm{~m}, 0.04 \mathrm{~Hz}$ & $\pm 8.42^{\circ}, 0.04 \mathrm{~Hz}$ & $\pm 7.27^{\circ}, 0.04 \mathrm{~Hz}$ \\
\hline 加算摇れ 5 & $\pm 0.04 \mathrm{~m}, 0.04 \mathrm{~Hz}$ & $\pm 0.42^{\circ}, 0.04 \mathrm{~Hz}$ & $\pm 8.27^{\circ}, 0.04 \mathrm{~Hz}$ \\
\hline
\end{tabular}

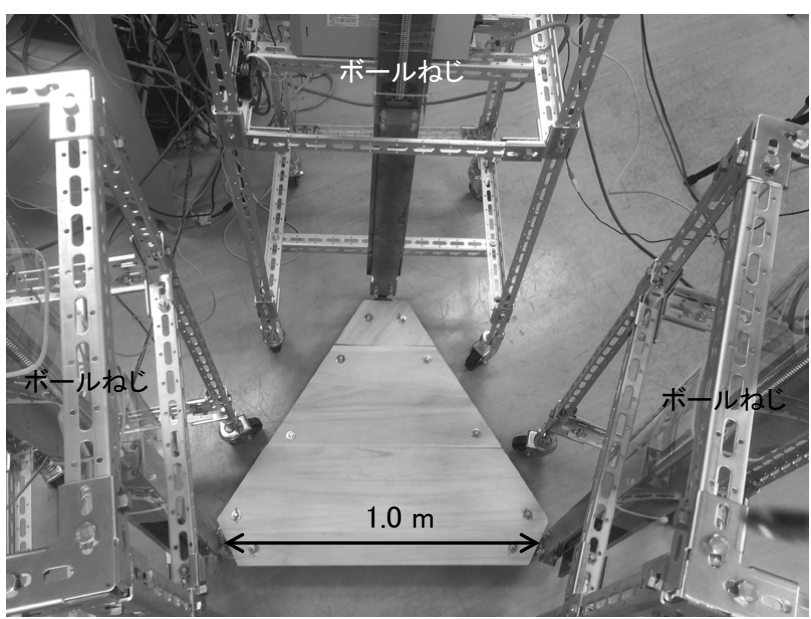

図 3 簡易型動摇装置の動摇面

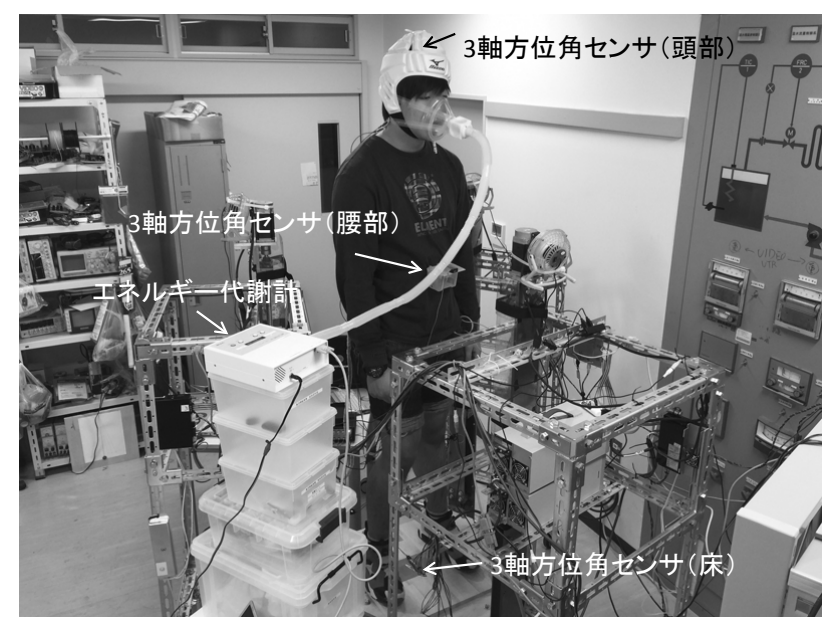

図 4 動摇装置を用いた実験風景 


\section{3. 結果}

\section{1 立位姿勢動摇}

小型船舶の動摇に対する被験者の動摇を図 5 に示 す。これは、14 名の被験者 (19～48 歳、男 6 名、女 8 名)の 22 例の実験データを対象に、座位姿勢から 立位姿勢になって 5 分経過後の 10 分間の有効なデー 夕について、船舶の床、被験者の腰部、頭部の加速 度・角加速度の実効值を求め平均值と標準偏差をプ ロットしたものである。ただし、図 5 で示したデー タは、簡易型動摇装置で発生させた動摇とは異なる 船舶の床の上下摇れ (Heave) の実効值が 0. 45 $1.27 \mathrm{~m} / \mathrm{s}^{2}$ の範囲から外れるデータを除外した。なお、 図 5 データは、スミルノフの棄却検定を行った結果、 有意水準 $5 \%$ で外れ值でないデータである。

動摇装置の動摇に対する被験者の動摇を図 6 に示 す。これは、5 名の被験者 (20〜24 歳、男 3 名、女 2 名)の 10 例の実験デー夕を対象に、座位姿勢から立 位姿勢になって 5 分経過後の 10 分間のデータについ て、被験者の腰部、頭部の加速度・角加速度の実効 值を求め、平均值と標準偏差をプロットしたもので ある。これらデータは、スミルノフの萧却検定を行 った結果、有意水準 $5 \%$ で外れ值でないデータである。

\section{2 運動負荷}

図 5、図 6 で用いた実験データに対応する小型船 舶における被験者の運動負荷、動摇装置における被 験者の運動負荷の平均值と標準偏差を図 7 に示す。

小型船舶における被験者の運動負荷、動摇装置に おける被験者の運動負荷における運動負荷を対象に 差があるかを、対応のない $\mathrm{t}$ 検定を用いて、有意水 準 5\%で検定を行った結果、有意差なしとなった。

\section{4. 考察}

我々の先行研究により、小型船舶の乗船者の立位 姿勢動摇は、船舶の床の上下摇れ (Heave) 発生時に、 他の方向の摇れが加わることで、関節を使った姿勢 制御が生じ、乗船者の腰部、頭部の回転方向に発生 することがわかっている ${ }^{(3)}$ 。本研究では、上下摇れ (Heave)、横摇れ (Roll)、縦摇れ (Pitch) を発生 させる簡易型動摇装置を用いて、小型船舶の乗船者 と同様な立位姿勢動摇と、運動負荷を発生させる環 境の構築を目指した。

本稿では、簡易型動摇装置を用いて、表 1 に示し た $\sin$ 波（正弦波）の動摇を発生させた。これは、 表 1 中の基本摇れに、基本摇れの周波数に対して相
対的に低い周波数の加算摇れを合成したものである。

図 6 より、動摇装置の動摇に対して、被験者が、 腰部、頭部の縦摇れ (Pitch)、船首摇れ (Yaw) 方向 の動きによって、姿勢制御を行う様子が示されてい る。しかし、動摇装置の床の横摇れ（Rol1）を基準 とした被験者の腰部、頭部の横摇れ（Ro11）の相対 的な值は、図 5 に比べて小さくなっている。これは、 動摇装置で発生させた動摇が、船舶動摇とは異なる ことを示唆する可能性がある。ただし、動摇装置の

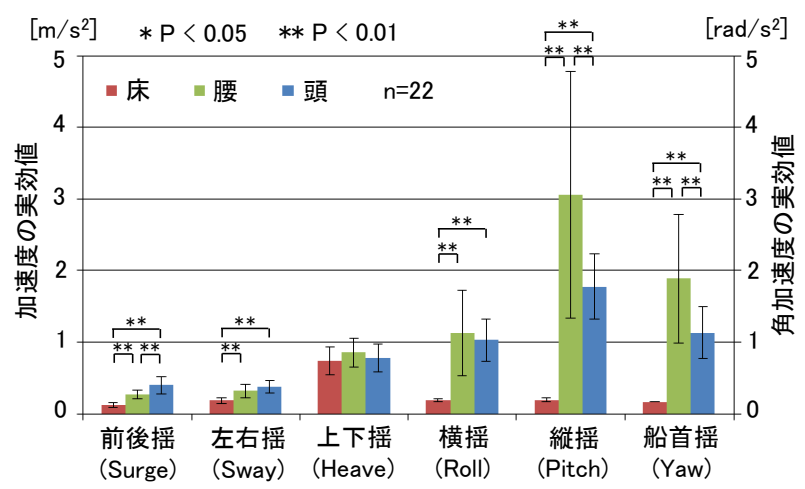

図 5 小型船舶における加速度 - 角加速度の実効值

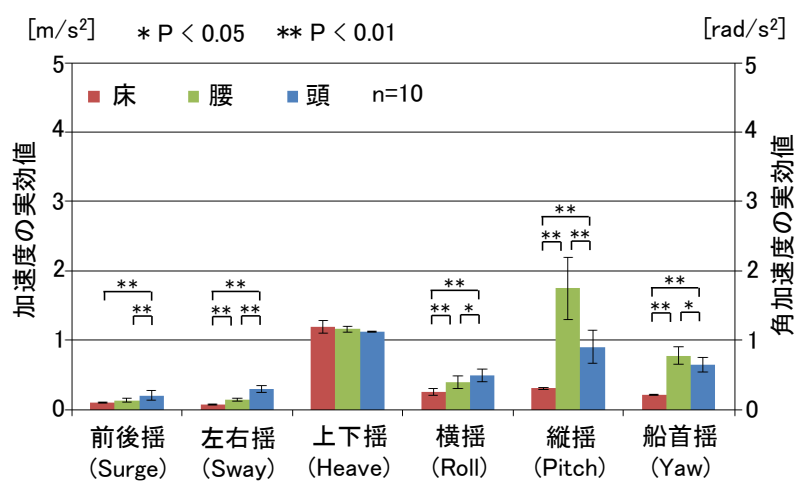

図 6 動摇装置における加速度・角加速度の実効值

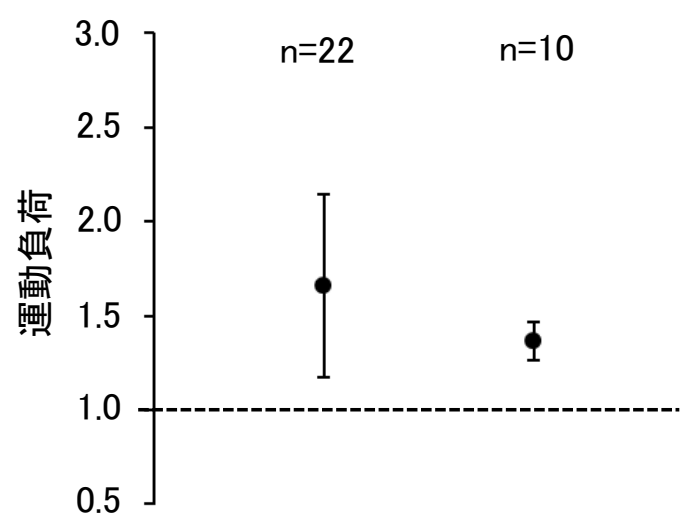

小型船舶 動摇装置

図 7 運動負荷 


\section{日本航海学会論文集 第134巻 第133回講演会にて講演}

動摇によって発生する運動負荷については、有意差 がないことから、船舶動摇によって発生する運動負 荷と同等な強度である可能性がある。

今回、簡易型動摇装置で発生させた動摇は、同一 パターンの上下摇れ (Heave)、横摇れ (Roll)、縦摇 れ（Pitch）を発生させていた。このため、被験者が 動摇装置の動摇に慣れ、船舶と異なった姿勢制御を 行った可能性もある。さらに、加速度 - 角加速度の 実効值は、高い周波数の加速度 - 角加速度で大きな 值を示寸傾向があるため、今後、小型船舶の床の動 摇解析を進め、動摇装置で再現する動摇パターンの 検討を行っていく必要がある。

\section{5. まとめ}

筆者らの先行研究における加速度・角加速度の実 効值の計測により、乗船者が船舶動摇に対して、頭 部、腰部の回転方向の動きによって立位姿勢を維持 していることを明らかにした ${ }^{(3)}$ 。さらに、その運動 負荷が、踏み台昇降運動に相当していることを明ら かにした ${ }^{(4)}$ 。

本研究では、並進運動としての上下摇れ (Heave)、 回転運動としての横摇れ（Roll）、縦摇れ（Pitch） の動摇を再現する簡易型動摇装置を用いて、加速 度 - 角加速度の実効值と運動負荷の視点で、動摇装 置の動摇と船舶動摇を評価する手法を提案し検証実 験を行った。検証実験により、動摇装置の動摇に対 して、被験者が、腰部、頭部の縦摇れ (Pitch)、船 首摇れ（Yaw）方向の動きによって、姿勢制御を行う 様子が示された。また、動摇装置の動摇によって、 船舶動摇と同等な強度の運動負荷が再現できた。

以上より、船舶動摇が乗船者に与える生理的影響 を解析するための研究環境構築において、加速度 · 角加速度の実効值と運動負荷を指標とする評価手法 が有効である可能性が示唆された。簡易型動摇装置 で発生させる動摇については、小型船舶で計測した データを基に、加速度・角加速度と、その実効值と の関係を精查し、発生させる動摇パターンを改善す ることで、実際の船舶と同等な動摇を再現できる可 能性がある。今後、簡易型動摇装置で発生させる動 摇パターンについて検討を行う必要が有る。また、 被験者の個体差について検討を行うため、同一の被 験者による評価を行う必要が有る。

\section{謝辞}

本研究は、JSPS 科研費 19651075、公益財団法人
長岡技術科学大学技術開発教育研究振興会による研 究助成 (2008 年)、公益財団法人日本科学協会の笹 川科学研究助成 (24-724、2012 年)、および鳥羽商 船高等専門学校校長裁量経費（教育研究活動支援） により実施したものです。本研究のデータ収集にお きましてご協力頂きました鳥羽商船高等専門学校の 皆様に厚く御礼申し上げます。

\section{参考文献}

（1）公益社団法人 日本海難防止協会: 海と安全 平 成八年版「海難審判の現況」概要, 454, pp. 1-28, 1996.

（2）公益社団法人日本海難防止協会: 海と安全 疲 労と海難 また幽水，456, pp. 1-10, 1997.

（3）土井根礼音, 坂牧孝規, 瀬田広明, 伊藤政光, 本間章彦. 福井康裕 : 船舶動摇に対する乗船者の 立位姿勢動摇の解析, ライフサポート, Vol.27, No. 2, pp. 45-53, 2015. 8.

(4) Renon Doine, Takanori Sakamaki, Hiroaki Seta, Masamitsu Ito, Akihiko Homma, Yasuhiro Fukui:The Exercise Load of Passengers' Postural Control Against Ship Motion Using Human Energy Expenditure, Advanced Biomedical Engineering, 4, pp. 164-165, 2015.

(5) 細谷憲政, 雨海照祥, 金子道夫, 田村俊世, 鳥井 嘉彦, 鈴木正成, 松末智, 太田壽城, 石川和子, 福永哲夫, 三橋扶佐子, 杉山みち子, 森脇久隆, 加藤昌彦: 今なぜエネルギー代謝かー生活習慣病 予防のために, pp. 83-95, 第一出版株式会社, 2005.

(6) Thor I. Fossen. : Handbook of Marine Craft Hydrodynamics and Motion Control, pp. 15-25, John Wiley \& Sons, Ltd., 2011.

（7）伊佐弘, 谷口勝則, 岩井嘉男, 吉村勉, 見市知 昭: 基礎電気回路 第 2 版, pp. 53-54, 森北出版 株式会社，2011.

(8) 朝山正己, 彼末一之, 三木健寿, 今村裕行, 大西 範和, 藤原素子, 宮側敏明, 村上太郎, 森悟, 寄 本明: 運動生理学, p. 54, 東京数学社, 2013. 